\title{
ANALISA PENGARUH KUALITAS PELAYANAN TERHADAP KEPUASAN NASABAH PADA PT. BANK MEGA SYARI'AH PADANG
}

\author{
Jhon Fernos, Yosef Eka Putra \\ Akademi Keuangan dan Perbankan Padang \\ jhonfernos@akbpstie.ac.id
}

\begin{abstract}
Satisfaction is feeling happy or disappointed someone who comes from a comparison between the impression of the performance (results) of a product with expectations. Satisfaction is a kind of step comparison between the experience of the evaluation results, can produce something spiritually comfortable, convenient not only because of imagined or expected. While customer satisfaction is a business strategy that consists of software and services designed to increase profits (profits), income (revenue) and customer satisfaction (customer satisfaction).This study aims to determine whether the customer satisfaction on the quality of service that has made Bank Mega Syariah meet the satisfaction level of its customers. As a financial institution for the people of Bank Mega Syariah trying to see firsthand the level of satisfaction of its customers by trying to implement a customer satisfaction Bank Mega Syariah. This research is qualitative. Data were obtained through questionnaires administered directly to the customer as a correspondent in this study. By using the analysis of test validity, reliability, and the F test and $T$ test researchers trying to see the impact of service quality on customer satisfaction Bank Mega Syariah. From observation and testing that has been done shows that the validity of the test results of all valid questions and all questions the reliability test reliably obtained, with a value of $38.327 \mathrm{~F}$ test with a significance level of 0.000 , far above 0.05 means tangible jointly independent variable (0.002), responsiveness (0.008), and assurance (0.032) significantly affects the dependent variable (Customer satisfaction), while the independent variable empathy (0.260) and Reliability (0124) had no significant effect on customer satisfaction in PT Bank Mega Syariah Padang.
\end{abstract}

Keywords: Service Quality, Customer Satisfaction

\section{PENDAHULUAN}

Dalam keadaan perekonomian yang semakin sulit ini banyak terjadi persaingan di berbagai bidang kehidupan, termasuk didalamnya persaingan dalam dunia bisnis. Banyak perusahaan yang saling berlomba untuk mendapatkan pangsa pasar, sehingga hal ini memacu perusahaan untuk berusaha terus maju dalam memperbaiki bisnisnya. Di samping itu dengan adanya kemajuan teknologi, perusahaan dituntut pula untuk dapat mengikuti perkembangan zaman agar tidak tertinggal dengan yang lainnya.

Supaya perusahaan dapat tumbuh dan berkembang dengan baik, maka perusahaan tersebut harus dapat mengantisipasi perkembangan ekonomi yang semakin kompetitif dengan melakukan strategi yang tepat agar tidak tersisih dalam persaingan. Selain itu perusahaan juga harus dapat mengantisipasi kecenderungan ekonomi di masa mendatang dan harus dapat bersaing dengan perusahaan lain yang bergerak di bidang yang sama. Hal itu dilakukan untuk mempertahankan kelangsungan hidup dan kemajuan perusahaan. 
Perusahaan dalam memasarkan barang dan jasa selalu dihadapkan pada pertanyaan, "mengapa konsumen membeli barang atau jasa tertentu?" jawabannya tidak dapat diterangkan secara langsung dari pengamatannya saja, tetapi dibutuhkan analisa perilaku konsumen yang lebih mendalam. Hal ini akan banyak membantu bagi manajer pemasaran untuk memahami "mengapa" dan "bagaimana" perilaku konsumen tersebut, sehingga perusahaan dapat mengembangkan, menentukan harga, mempromosikan, dan memdistribusikan barangnya secara baik (Swastha, 2000 : 13). Dengan analisa perilaku konsumen ini, perusahaan akan mempunyai pandangan yang lebih luas dan akan lebih mengetahui kesempatan baru yang berasal dari belum terpenuhinya kebutuhan konsumen.

Perusahaan melihat pergeseran dan perubahan keinginan serta kebutuhan para konsumen membuat perusahaan kewalahan dalam menyusun strategi untuk memenangkan persaingan dalam dunia bisnis yang diakibatkan kemajuan zaman. Dimana kepuasan konsumen sangat diutamakan sehingga dapat memperoleh keuntungan yang diharapkan untuk membiayai kelangsungan operasi perusahaan.

Begitu juga halnya perusahaan Perbankan, kebutuhan masyarakat akan fungsi bank sebagai penyalur uang dan tempat peminjaman uang untuk bisnis membuat Bank menjadi sangat dibutuhkan masyarakat. Dan peluang ini membuka kesempatan bagi para Banker mengambil kesempatan ini dan disinilah di mulai persaingan antar Bank untuk memperoleh ruang di hati para nasabah

Namun persaingan bisnis Bank menuntut pelayanan yang baik bagi Konsumen yang dalam perbankan di sebut nasabah ini adalah raja yang harus dilayani dengan baik. Secara umum bank harus menerapkan strategi bisnis kombinasi antara strategi ofensif dan defensif. Dimana strategi ofensif perlu ditujukan untuk meraih atau memperoleh nasabah baru, sedangkan untuk meningkatkan pangsa pasar dan strategi defensif berusaha untuk mengurangi kemungkinan customer exit dan beralihnya konsumen dari perusahaan.

Kepuasan konsumen dipengaruhi dua variabel utama, yaitu Expectations dan Perceived Performance, bila Perceived Performance melebihi Expectations, maka konsumen mendapatkan kepuasan, akhirnya akan menciptakan loyalitas konsumen (Tjiptono, 2000: 41). Menurut Tjiptono (2000:70) ada beberapa faktor yang menentukan kualitas jasa, yaitu:

1. Tangibles (berwujud) yaitu bukti fisik dari jasa, bisa berupa fasilitas fisik, peralatan yang digunakan, representasi fisik dari jasa.

2. Empathy (empati) meliputi kemudahan dalam hal melakukan hubungan komunikasi yang baik, perhatihan pribadi dan memahami kebutuhan pelanggan

3. Reliability (kehandalan) kemampuan memenuhi janji layanan secara cepat, akurat dan memuaskan.

4. Responsifines (ketanggapan) merupakan keingginan para staf untuk membantu para pelanggan dan member pelayanana dengan tanggap.

5. Assurance (Jaminan) Mencakup pengetahuan, kemampuan, kesopan an dan keragu raguan.

Hal yang perlu diperhatikan dalam memberikan pelayanan adalah mendengar suara nasabah, hal ini berarti Bank harus melakukan interaksi dengan nasabah dengan maksud untuk memperoleh umpan balik (feed back) berapa tanggapan nasabah tentang sarana dan prasarana yang berhubungan dengan pelayanan yang diberikan sebagai kontrol dan ukuran keberhasilan.

Adapun cara untuk mendapat-kan umpan balik disini diantaranya dapat dilakukan dengan penerapan sistem keluhan dan saran atau dengan survei loyalitas nasabah maka keluhan atau ketidakpuasan nasabah tersebut dapat segera diambil dan ditentukan solusi yang terbaik oleh bank.dan kendala-kendala yang dihadapi oleh nasabah. Seperti sulitnya 
untuk meluangkan waktu untuk datang ke Bank atau sulitnya menyetorkan uang dalam jumlah yang banyak ke bank.

PT Bank Mega Syariah cabang padang adalah lembaga keuangan memberikan layanan jasa keuangan syariah bagi semua kalangan melalui kinerja organisasi yang unggul, dengan cara memberikan pelayanan bagi semua nasabah yang ada di PT Bank Mega Syariah seperti memberikan pelayanan kepada nasabah yang mendapatkan pembiayaan maka Bank akan memberikan pelayanan antar jemput anggsuran tanpa di pungut biaya, bagi nasabah yang mempunyai tabungan juga di berlakukaan pelayanan antar jemput uang yang mau di setorkan ke rekening nasabah, dan juga bagi nasabah yang memiliki deposito di PT Bank Mega Syariah juga di berikan pelayanan untuk membantu transaksi si nasabah, untuk memberikan pelayanan ini maka dari bank sendiri akan menugas satu orang teller dan satu orang security dengan di buatkan surat tugas untuk melaksanakan pekerjaan ini, pelayanan ini di berikan agar meningkatkan stakeholder dalam mewujudkan kesejahteraan bangsa.

Tabel 1

Jumlah Nasabah, Jumlah Pengimpunan dan Penyaluran Dana

\begin{tabular}{|c|c|c|c|c|}
\hline \multirow{2}{*}{ Tahun } & Jumlah & \multicolumn{3}{|c|}{ Jenis Produk } \\
\cline { 3 - 5 } & Nasabah & Tabungan (Rp) & Deposito (Rp) & Pembiayaan (Rp) \\
\hline 2008 & 750 Orang & $390.000 .000,-$ & - & $9.800 .000 .000,-$ \\
\hline 2009 & 1.380 Orang & $650.000 .000,-$ & $15.700 .000 .000,-$ & $18.000 .000 .000,-$ \\
\hline 2010 & 1.890 Orang & $930.000 .000,-$ & $40.600 .000 .000,-$ & $45.000 .000 .000,-$ \\
\hline 2011 & 2.450 Orang & $1.190 .000 .000,-$ & $56.000 .000 .000,-$ & $60.000 .000 .000,-$ \\
\hline 2012 & 3.650 Orang & $1.489 .000 .000,-$ & $75.500 .000 .000,-$ & $98.560 .000 .000,-$ \\
\hline
\end{tabular}

Sumber : Data diolah sendiri, 2013

Dari data table 1 terjadi peningkatan jumlah nasabah, jumlah tabungan, jumlah deposito, dan jumlah pembiayaan untuk per tahunya, untuk tabungan terjadi peningkatan karena adanya jenis tabungan haji (Iswatt ISMDR), tabungan pembiayaan (Iswatt Mitra), tabungan biasa (Iswat Tama), Tabungan Karyawan (iswatt Staf), sedangkan produk deposito masukanya ke tabungan iswat Tama (tabungan biasa) untuk pembiayaan masuk dalam tabungan (Iswatt Mitra)

Dengan semakin meningkatnya akan kebutuhan, tabungan, deposito dan simpan pinjam, memberikan peluang bagi bank. Dengan semakin meningkatnya usaha tersebut, dan untuk mempertahankan loyalitas nasabah bank memberikan pelayanan yang terbaik bagi masyarakat. maka peneliti sangat tertarik untuk mempelajari atau menganalisis tentang "Analisis Pengaruh Kualitas Pelayanan Terhadap Kepuasan Nasabah Pada PT Bank Mega Syari'ah Padang

Berdasarkan latar belakang tersebut maka perumusan masalahnya adalah sebagai berikut:

1. Bagaimanakah pengaruh tangibles (berwujud) terhadap kepuasan nasabah pada PT Bank Mega Syariah Padang?

2. Bagaimanakah pengaruh Empathy (empati) terhadap kepuasan nasabah pada PT Bank Mega Syariah Padang?

3. Bagaimanakah pengaruh Reliability (kehandalan) terhadap kepuasan nasabah pada PT Bank Mega Syariah Padang?

4. Bagaimanakah pengaruh Responsiveness (ketanggapan) terhadap kepuasan nasabah pada PT Bank Mega Syariah Padang?

5. Bagaimanakah pengaruh Assurance (jaminan) terhadap kepuasan nasabah pada PT Bank Mega Syariah Padang? 


\section{KERANGKA TEORITIS DAN HIPOTESIS}

\section{Pemasaran dan konsep pemasaran}

Kotler (2007) Mendefenisikan Manajement pemasaran sebagai: proses perencanaan dan pelaksanaan dari perwujudan pemberian harga dan promosi dan distribusi dari barang barang dan jasa dan gagasan untuk menciptakan pertukaran dengan kelompok sasaran yang memenuhi tujuan pelanggan dan organisasi.

Menurut Stanton (2007) pemasaran adalah sistem keseluruhan dari kegiatan usaha yang ditujukan untuk merencanakan, menentukan harga, mempromosikan dan mendistribusikan barang dan jasa yang dapat memnuaskan kebutuhan pembeli maupun pembeli potensial. Pemasaran merupakan factor yang dalam mencapai keberhasilan. Suatu usaha untuk mencapai keberhasilan harus me-ngtahui cara dan falsafah yang terlibat didalamnya. Cara dan falsafah ini disebut konsep pemasaran bertujuan untuk memberikan kepuasan terhadap keinginan dan kebutuhan konsumen.

\section{Konsep Jasa}

Dalam kondisi bisnis sekarang ini kehidupan masyarakat secara keseluruhan selalu berhubungan dengan produk dan jasa. Defenisi jasa" setiap tindakan atau kinerja yang ditawar oleh satu pihak ke pihak lain, secara prinsip tidak berwujud dan tidak menyebabkan perpindahan kepemilikan. Produksi jasa dapat terikat atau tidak terikat pada suatu produk fisik. Kotler dan Keller $(2006$; 372)

Secara khusus jasa mempunyai karakteristik utama dimana karakteristik nya sangat mempengaruhi program pemasaran. Karakteristik tersebut yaitu:

\section{Inseparability}

Disini produsen dan konsumen berjalan searah, maksudnya si penghasil jasa dan si pemakai jasa hadir secara pisik saat jasa tersebut di konsumsi. Jasa biasanya dikonsumsi telebih dahulu, baru kemudian di produksi dan di konsumsi secara bersama.

\section{Variability}

Bersifat sangat variable karena merupakan standardized output maksudnya banyak variasi bentuk, kualitas dan jenis, tergantung pada kapan dan dimana jasa tersebut dihasilkan.

\section{3 .Perisability}

Jasa merupakan komoditas tidak tahan lama dan tidak dapat disimpan. Dalam kasus tersebut jasa dapat disimpan dalam bentuk pesanan. Peningkatan permintaan akan suatu jasa pada saat sepi dan penundaan penyampaian jasa.

\section{Intangibility}

Jasa besifat ingtability maksudnya jasa bisa dilihat, dihaba, dicium atau didengar sebelum dibeli. Zeitmal dan binter dalam tjiptono (2000)

\section{Konsep kepuasan pelanggan}

Kepuasan pelanggan adalah: persepsi pelanggan bahwa harapannya telah terpenuhi atau terlampaui." Gerso ricard (2000)

Alasan perlunya diberkan pelayanan yang baik kepada pelangan antara lain:

1. Kepuasan pelanggan adalah usaha yang berulang ulang bersumber dari keuntungan masa yang akan datang.

2. Kesan pelangan dikemukakan oleh sikap kita dan kualitas dari pelayanan yang kita berikan. Mussalman dan jakson(1984)

Philip kotler dalam Fandy Tjiptono (2000) mendefinisikan kepuasan pelanggan sebagai tingkat perasaan seseorang setelah membanding kan kinerja(hasil) yang dia rasakan dibandingkan dengan harapan. Definisi tersebut diatas dapat diuraikan lebih lanjut bahwa tingkat kepuasan adalah fungsi dari perbedaan antara kinerja yang dirasakan dengan harapan. 
Banyak peusahaan berfokus pada kepuasan tinngi karena para pelanggan yang hanya puas mudah untuk berubah pilihannya bila mendapatkan penawaran yang lebih baik. Namun mereka yang amat puas lebih sukar untuk mengubah pilihannya.

\section{Manfaat Kepuasan Pelanggan}

Manfaat kepuasan pelangan (coustomer satisfaction) bagi penyelia jasa adalah:

\section{Stay longer}

Dengan tercapainya kepuasan pelanggan secara kontiniu maka loyalitas pelanggan dapat tercapai. Meraka yang telah loyal akan sulit pindah ke penyelia jasa lainnya. Dan tentu saja akan berpengaruh kepada profitalitas perusahaan.

2. Buys more company introdus new product and upgrades exsting product. Pelanggan akan jadi teman baik bagi perusahaan yang mempecayainnya.

3. Talks favorably about the company and its poduct

Jika pelanggan puas maka ia akan menyebarkan pengalamannya dan inilah yang disebut word of mouth yang positif

4. Offers product ideas to the company

Karena selalu merasa puas maka pelanggan tidak akan berpaling ke product lain.

\section{Pengukuran kepuasan pelanggan}

Menurut kotler dalam mengukur kepuasan pelangan, ada emapat metode yang paling banyak yang digunakan Tjiptono (2000) yaitu:

\section{1. $\quad$ Sistem keluhan dan saran}

Setiap organisasi jasa yang berorientasi pada pelanggan wajib memberikan kesempatan yang seluas -luasnya bagi para pelanggan menyampaikan saran, kritik, pendapat dan keluhan meraka. Informasi - informasi yang diperoleh melalui metode ini dapat memberi kan ide baru dan masukan berharga bagi perusahaan

\section{Gost Shoping}

Salah satu cara memperoleh gambaran mengenai kepuasan pelanggan adalah dengan memper kerjakan beberapa orang gost shopper untuk berperan sebagai pelanggan potensial jasa dan pesaing. Para gost shopper juga dapat mengobservasi cara perusahaan pesaing melayani permintaan spesifik pelanggan, menjawab pertanyaan pelanggan dan mengenai setiap masalah atau keluhan pelanggan.

\section{Lost costumer analysis}

Perusahaan menghubungi para pelanggan yang telah berhenti agar dapat memahami mengapa hal itu terjadi dan dapat mengambil kebijaksanaan perbaikan atau peyempurnaan selanjutnya.

\section{Survey kepuasan pelanggan}

Umunya penelitian mengenai kepuasaan pelanggan dilakukan dengan metode survey, telepon email maupun wawancara langsung. Perusahaan akan memperoleh tanggpan dan umpan balik langsung dari pelanggan dan member sinyal positif bahwa perusahaan menaruh perhatiaan terhadap mereka.

\section{Harapan Pelanggan}

Harapan merupakan perkiraan atau keyakinan pelanggan tentang apa yang diterimanya. Pada dasarnya ada hubungan yang erat antara penentuan kualitas dan harapan sebagai standar atau acuan terhadap produk yang dikonsumsi. Menurut olsen dover harapan pelanggan Tjiptono (2000) merupakan keyakinan pelanggan sebelum mencoba atau membeli sebuah produk, yang dijadikan standart atau acuan dalam menilai kinerja tersebut.

Harapan pelanggan mempunyai peranan penting dalam menentukan kualitas produk dan kepuasan pelayanana. Ketika harapan penerima jasa yang diterima kualitas sangat luar biasa berarti akan memberikan kepuasa dan kesenangan bagi pelanggan. Pada 
saat harapan penerima jasa tidak terpenuhi berarti berarti kulitas produk tidak dapat diterima jasa akan puas dengan kualitas produk tersebut.

\section{Layanan}

Defenisi Layanan

Pelayanan merupakan penunjang pemawaran suatu produk atau jasa. Diabaikannya pelayanan dalam kegiaatan pemasaran bisa menimbulkan rasa yang tidak puas dari pihak langgannan dan akan merugikan pihak produsen. Pelayanan yang dimaksud oleh Michael le bouf adalah bagaimana memahami masalah yang dihadapi pelanngan dan menawarkan pemecahan sekaligus membantu pelanggan itu agar lebih beruntung dan merasa senagn dengan transaksi tersebut. Michael le bouf,(1992)

\section{Deferensiasi layanan}

Dalam menghadapi persaingan yang semakin ketat, perusahaan harus meningkatkan pelayanan terhadap konsumen dan hendaknya mampu memberikan pelayanan yang baik. Untuk itu perusahaaan perlu melakukan deferensiasi terhadap pelayanan yang diberikan kepada konsumen

Deferensiasi maksudnya bagaimana pelayanan jasa dapat memberikan pelayanan terhadap pesaing serta mampu mempertahankan kualitas dari perbeda tersebut dengan terus melakukan inofasi inofasi layanan

\section{Kualitas Pelayanan/ Jasa.}

Tujuan perusahaan memberikan pelayanan yang baik adalah untuk dapat memuaskan para pelangan sehingga mereka puas atas pelayanan yang diberikan. Pihak perusahaan haru berusaha meningkatkan kualitas jasa atau pelayanan secara kontiniu

Pada dasarnya kualitas jasa berfokus pada upaya kebutuhan dan keinginan pelanggan serta ketepatan penayampaian untuk mengimbangi harapan pelanggan. Hal ini harus berarti bahwa citra kualitas yang baik bukanlah berdasarkan sudut pandang atau persepsi pihak penyelia jasa melainkan berdasarkan sudut pandang atau persepsi pelanggan

Pasuraman, zeithtam dan berry membentuk model kualitas jasa yang menyoroti syaratsyarat utama untuk memberikan kualitas jasa yang diharapkan.

5 (lima) kesenjangan yang ter-identifikasi pada gambar diatas yang mengakibatkan kegagalan penyampai-an jasa yaitu:

1. Kesenjangan antara harapan konsumen dan persepsi managemen. Managemen tidak selalu memahami benar apa yang menjadi keingginan pelanggan.

2.Kesenjangan antara persepsi manajemen dengan spesifikasi kualitas jasa. Management benar dalam memahami keinginan pelanggan tapi tidak menetapkan standar pelaksanaan yang spesifikasi.

3. Kesenjangan antara kualitas jasa dan penyampaian jasa. Para karyawan tidak terlatih dan tidak memenuhi standar pelaksanaan.

4. Kesenjangan antara penyampaian jasa komunikasi eksternal. Harapan konsumen dipenuhi oleh pernyataan yang dibuat oleh wakil perusahaan maupun dari komunikasi dari mulut ke mulut.

5. Kesenjangan antara yang dialami dan jasa yang diharapkan. Terjadi bila konsumen kinerja perusahaaan dengan cara yang berbeda dan memiliki persepsi yang keliru mengenai kualitas jasa.

Para pakar pemasaran seperti parasuraman, zeithalm, dan berry yang memerlukan penelitian khusus terhadap beberapa jenis jasa dan berhasil mengidentifikasi sepuluh faktor utama yang menentukan kualitas jasa. Kesepuluh faktor tersebut (parasuraman dkk. 1985 dalam tjiptono, 2000) meliputi:

1. Reability mencakup dua hal pokok yaitu konsistensi kerja dan kemampuan untuk percaya. Hal ini berarti perusahaan memberikan jasanya secara tepat, selain itu juga 
perusahaan yang bersangkutan memenuhi janji, misalnya menyampaikan jasa sesuai dengan jadwal yang disepakati.

2. Responsiveness yaitu kemampuan atas kesiapan para karyawan memberikan jasa yang dibutuhkan pelanggan.

3. Competence artinya setiap orang dalam suatu perusahaanmemiliki keterampilan dan pengetahuan yang dibutuhkan agar dapat memberikan jasa tertentu

4.Access meliputi kemudahan sihubungi dan ditemui. Hal ini berarti lokasi fasilitas jasa yang mudah dijangkau, waktu menungggu yang tidak terlalu lama, saluran komunikasi perusahaan yang mudah dihubungi.

5. Courtesy, meliputi sikap sopan ssantun, respek,perhatian dan keramahan yang dimiliki para contact personel

6. Communication, artinya memberi-kan informasi kepada pelanggan dalam bahasa yang dapat dipahami serta selalu mendengarkan saran dan keluhan pelanggan.

7. Credibilitas, yaitu sifat jujur yang dapat dipercaya. Kredibilitas mencakup nama baik perusahaan, reputasi perusahaan, karakteristik pribadi contact personal dan interaksi dengan pelanggan.

8. Security yaitu aman dari bahaya, resiko atau keragu raguan. Aspek ini meliputi keamanan secara fisik, keamanan financial dan kerahasiaan.

9. Understanding yaitu usaha untuk memahami pelanggan.

10 .Tangibles, yaitu bukti fisik dari jasa, bisa berupa fasilitas fisik, peralatan yang digunakan, representasi fisik dari jasa.

Selanjutnya pasuraman (1988) menemukan bahwa sepuluh yang ada dapat dirangkum menjadi hanya lima dimensi pokok ( Tjiptono, 2000) :

1. Tangibles yaitu bukti fisik dari jasa, bisa berupa fasilitas fisik, peralatan yang digunakan, representasi fisik dari jasa.

2. Reability kmampuan memenuhi janji layanan secara cepat, akurat, dan memuaskan.

3.Responsiveness, ini merupakan keingginan para staff untuk membantu para pelanggan dan memeberikan pelayanan dengan tanggap

4. Assurance mencakup pengetahuan, kemampuan, kesopanan dan keragu-raguan.

5. Empathy, meliputi kemudahan dalam melakukan hubungan, komunikasi yang baik, perhatian pribadi, dan memahami kebutuhan pelanggan. 


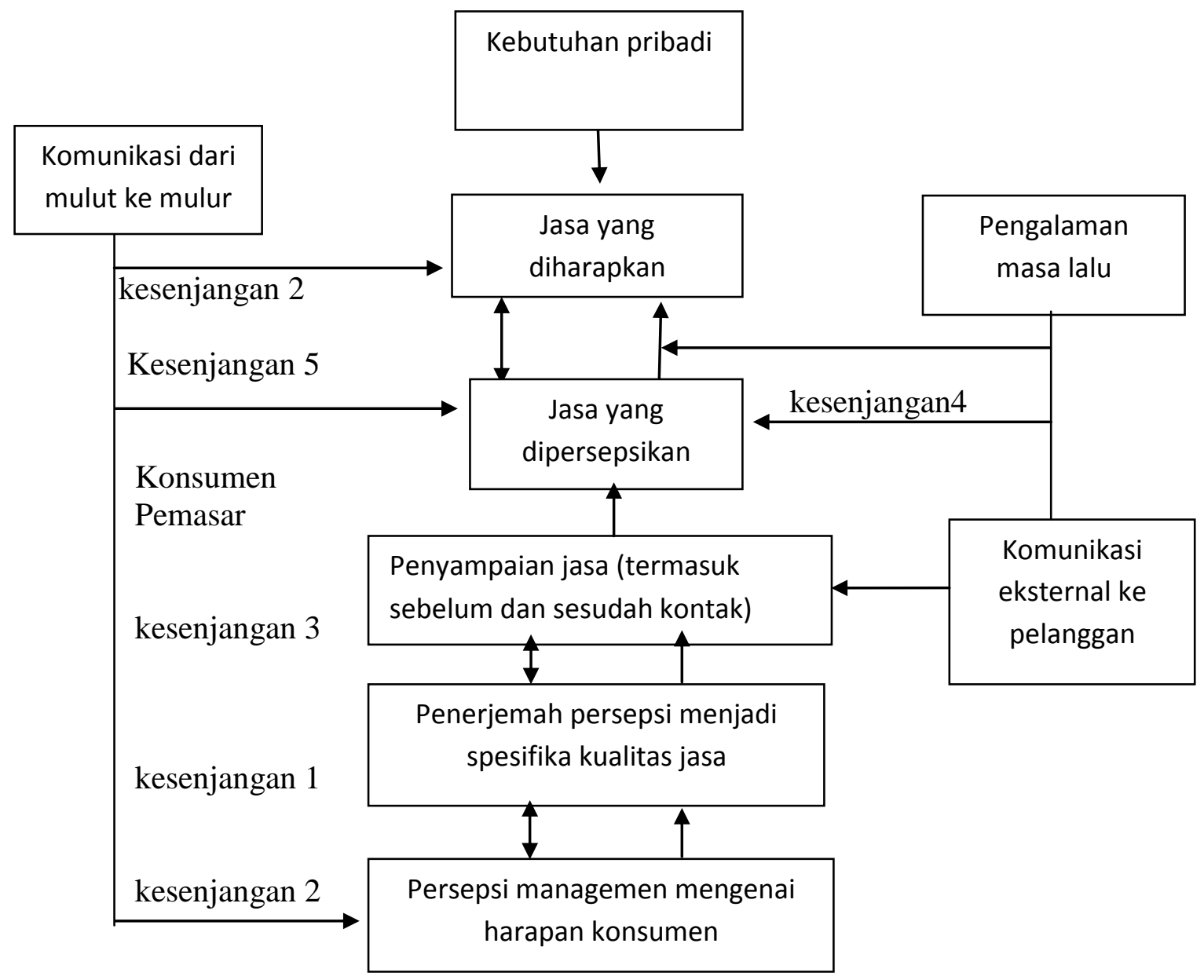

Gambar 2.1 Mode Kualitas Jasa Sumber : Parsuraman (2003)

\section{Hubungan antara Kualitas Pelayanan dan Kepuasan Konsumen}

Kepuasan adalah perasaan senang atau kecewa yang muncul setelah membandingkan antara proyeksi atau kenyataan terhadap kinerja suatu produk dan harapan - harapannya. Kepuasan merupakan fungsi persepsi atau kesan atas kinerj atau harapan.

Kepuasan pelangan dapat sipengaruhi oleh banyak factor diantaranya adalah kualitas pelayanan . pelayanan masyarakat adalah setiap upaya yang dilakukan secara sendiri atau bersama - sama dalam suatu organisasi untuk memelihara dan meningkatkan kepuasan masyarakat.

Hasil penelitian Sweeney dan soutar (2001) menemukan bahwa kualitas pelayanan berpengaruh signifikan terhadap kepuasan pelanggan. Sedangkan hasil penelitian garbarino johson (1999) mengungkap-kan bahwa kualitas pelayanan berpengaruh terhadap kepuasan konsumen.Berdasarkan yondri (2008) diketahui bahwa hanya dimensi tertentu dari kualitas pelayanan (empathy, reliability, dan assurance) yang berpengaruh signifikan terdap kepuasan konsumen.

\section{Penelitian Terdahulu}

Penelitian ini telah pernah di lakukan Siska Humahera pada tahun 2010 yang di lakukan pada Bank Syariah Mega Indonesia Distrik Padang, dengan hasil:

Besarnya pengaruh kualitas pelayanan (tangibles, empathy, reliability, respon-siveness, dan assurance) terhadap kepuasan nasabah pada Bank Syariah Mega Indonesia.

Hasil analisa statistik dengan mengguna kan regresi berganda menunjukkan bahwa secara parsial (Uji t)dimensi kualitas pelayanan tangibles, responsive ness, dan assurance, berpengaruh signifikan terhadap kepuasan nasabah dalam pemberian pelayanan pada Bank Syariah Mega Indonesia. 


\section{Hipotesis}

Bedasarkan perumusan masalah, tujuan penelitian dan kerangka konseptual penelitian, maka berikut ini dapat dikembangkan hipotesis penelitian sebagai berikut:

1. Variable tangibles berpengaruh signifikan positif terhap kepuasan nasabah pada PT Bank Mega Syariah Padang

2. Variable Empathy berpengaruh signifikan positif terhap kepuasan nasabah pada PT Bank Mega Syariah Padang

3. Variable Reliability berpengaruh signifikan positif terhap kepuasan nasabah pada PT Bank Mega Syariah Padang

4. Variable Responsiveness berpengaruh signifikan positif terhap kepuasan nasabah pada PT Bank Mega Syariah Padang

5. Variable Assurance berpengaruh signifikan positif terhap kepuasan nasabah pada PT Bank Mega Syariah Padang.

\section{METODOLOGI}

\section{Objek Penelitian}

Dalam kasus ini penulis mengambil objek penelitian pada PT Bank Mega Syariah Padang. Yaitu mengenai pendapat nasabah PT Bank Mega Syariah Padang yang mendapatkan pelayanan dari pihak bank.

\section{Populasi dan Sampel Penelitian.}

Dalam penelitian ini populasi dan sampel adalah nasabah PT Bank Mega Syariah Padang. Untuk menentukan sampel yang akan digunakan dalam suatu penelitian terdapat berbagai teknik sampling yang digunakan dalam suatu penelitian. Teknik sampling misalnya yang digunakan yaitu probability sampling dan non sampling. Dalam kasus ini poeneliti mengunakan teknik probability sampling dengan cara simple random sampling. Cara demikian dilakukan karena anggota populasi dianggap homogeny atau setiap unsur populasi memberikan peluang yang sama untuk dipillih menjadi anggota sampel.

Untuk menentukan ukuran sample dari populasi dapat digunakan rumus slovin (husein umar,1999) sebagai berikut:

$$
n=\frac{\mathrm{N}}{1+\mathrm{Ne}^{2}}
$$

Dimana $: \mathrm{n}=$ Besar sample

$\mathrm{N}=$ Besar populasi

$\mathrm{e}=$ persentase kelongaran ketidak pastian karena kesalahan

pengambilan sampel masih di tolerir 
disini peneliti mengambil jumlah populasi pada jumlah nasabah pada tahun 2008 - 2012 yaitu 3650 orang dan jumlah sampel yang diambil sebesar $10 \%(\mathrm{e}=10 \%)$.

$$
\begin{aligned}
n & =\frac{3650}{1+3650(0.1)^{2}} \\
& =97,33
\end{aligned}
$$

Digenapkan menjadi 97,33 jadi peneliti mengambil jumlah sampel sebanyak 100 orang sebagai responden untuk memperkuat keakuratan data.

\section{Jenis Dan Sumber Data}

\section{Jenis Data}

\section{a. Data kuantitatif}

Adapun jenis data yang di gunakan adalah sebagai berikut :

Adalah data yang diperoleh oleh perusahaan yang dapat di buktikan dengan angka-angka yang akan dioolah dan dianalisa sesuai dengan metode analiss sehingga dapat terlihat dari hasilnya.

\section{b. Data kualitatif}

Adalah data yang di peroleh dari hasil wawancara dengan pihak-pihak yang berkepentingan berupa data lisan dengan penjelasan mengenai pembahasan.

\section{c. Sumber Data}

Untuk menunjung kelengkapan pembahasan dalam penulisan ini. Penulis memperoleh data yang bersumber dari :

a. Data Primer

b. Data Sekunder

Data Primer

Data primer menurut (Husein Umar, 2003) adalah data yang di peroleh peneliti dari sumber pertama baik dari individu atau perorangan, seperti hasil wawancara atau hasil pengisian kuesioner. Dalam penelitian ini untuk mendapatkan data primer dapat dilakukan dengan cara penyebaran kuesioner langsung kepada nasabah PT Bank Mega Syariah Padang.

Data Sekunder

Data sekunder menurut (Husein Umar, 2003) adalah data primer yang telah diolah lebih lanjut dan disajikan baik oleh pihak pengumpul data primer atau pihak lain. Data sekunder dalam penelitian ini di peroleh dari data-data PT Bank Mega Syariah Padang. Data sekunder dalam penelitian ini sejarah singkat PT Bank Mega Syariah dan jumlah nasabah pada tahun 2008 - 2012

\section{d. Metode Pengumpulan Data}

\section{a. Library Research (Riset kepustakaan)}

yaitu pengumpulan data melalui bahan publikasi, laporan, buku buku dan studi kepustakaan lainya yang berhubungan dengan masalah yang dibahas.

b.Field Research (Riset Lapangan)

Yaitu melalui peninjauan dengan turun ke lapangan langsung pada objek penelitian untuk mendapatkan data dan informasi yang dibutuhkan yaitu melalui:

1. Wawancara: melakukan pe-ngumpulan data dari pejabat atau sumber yang berwenang dan berkepentingan dalam penelitian ini.

2. Observasi: langsung melakukan terhadap aktifitas yang dilakukan perusahaan tersebut.

3. Kuesioner: melalui beberapa pertanyaan yang disusun sedemikian rupa untuk mengetahui pengaruh layanan terhadap kepuasan nasabah pada Bank Mega Syariah Padang. Kuesioner ini diajukan kepada 100 nasabah dengan menguna-kan metoda sample convenience yaitu sample yang diambil sedemikian rupa dimana anggota sample yang dipilih karena mereka mudah dijangkau dan cocok dengan sumber data. 


\section{e. Defenisi Operationalisasi Variable Penelitian}

Penelitian ini mengunakan 5 (lima) variable bebas yaitu tangibles (X1), Empathy (X2), Reliability (X3), Responsiveness (X4), Assurance (X5) dan memiliki 1 (satu) variable terikat yaitu kepuasan nasabah (Y) berikut ini akan diuraikan kosep dan operasionalisasi masing - masing variable.

\section{Kepuasan Nasabah}

Dalam penelitian ini, kepuasan nasabah (customer statisfaction) merupakan variable terikat (independent variable). Penelitian ini mendefenisikan atau memberikan konseptual terhadap kepuasan nasabah sebagai perasaan senang atau kecewa seseorang terhadap kinerja (hasil) pihak bank. Selanjutnya, variable kepuasan nasabah ini dioperasionalisasikan melalui 5 (lima) butir pertanyaan yang di adaptasi dari Sweeney dan soutar (2001) dan diukur dengan mengunakan skala likert-5 yaitu $1=$ sangat tidak setuju, $2=$ tidak setuju, $3=$ netral, $4=$ setuju, $5=$ sangat setuju.

\section{Kualitas pelayanan}

Dalam pelayanan ini kualitas pelayanan didefenisikan sebagai segala usaha yang dilakukan oleh pihak bank. Variable kualitas pelayanan ini dioperasionalisasikan melalui 5 (lima) dimensi yaitu tangible, empathy, reliability, responsiveness, assurance, masing masing dimensi tersebut diukur dengan mengunakan 4 (empat) petanyaan dengan skala likert -5 yaitu $1=$ sangat tidak setuju, $2=$ tidak setuju, $3=$ netral, $4=$ setuju, $5=$ sangat setuju

\section{f. Metodologi}

Untuk menganalisa data dalam penelitian ini akan mengunakan beberapa teknik analisa statistic melalui pemanfaatan statistical Package for social science (SPSS) versi 13.0 for windows antara lain adalah:

1. Statistik deskriptif

Statistik deskriftip adalah metode statistik yang digunakan untuk mengambarkan atau mendeskripsikan data yang telah dikumpulkan menjadi sebuah informasi (kuncoro,2003). Analisa statistic desskriptif digunakan mendeskripsikan profil responden, nilai rata - rata variable kualitas pelayanan dan kepuasan nasabah serta distribusi frekuenssi jawaban responden terhadap masing - masing penyataan pada variable penelitian.

2. Uji Validitas dan Reliabilitas

Validitas adalah suatu skala pengukuran disebut valid bila ia melakukan apa yang seharusnya dilakuan dan mengukur apa yang seharusnya diukur (Kuncoro 2003; Sekaran 2003). Untuk mengetahui apakah pertanyaan - pertanyaan valid atau tidak, maka digunakan vibariate correlation yaitu mengkorelasikan msing - masing item pertanyaan terhadap total item pertanyaan (ghozalli, 2005). Apabila item pertanyaan berkorelasi signifikan dengan total item pertanyaan maka item tersebut dinyatakan valid, dan sebaliknya

Reabiabilitas adalah menurut sekaran (2003:422) reability is the consistency and stability of the measuring instrument. Pengertian tersebut dapat diartikan bahwa reliabilitas merupakan kosistensi dan stabilitas dari pengukuran instrument. Dengan demikian, reliabilitas mencakup dua hal utama yaitu stabilitas ukuran dan konsistesi internal ukuran. Untuk mengetahui reliabilitas variable tangible (X1), emphathy (X2), reliability (X3), responsiveness (X4), Assurance (X5) dan kepuasan masyarakat (Y), digunakan Cronbach,s alpha minimal 0,70 (sekaran,2003)

3. Analisa Regresi Linear Berganda

Analisis regresi adalah suatu teknik statistic yang digunakan untuk mengetahui seberapa besar pengaruh variable bebas terhadap variable terikat (kuncoro,2003). Oleh karena itu tujuan mengunakan analisa regresi dalam penelitian ini adalah untuk mengetahui seberapa besar pengaruh variable dimensi kualitas pelayanan (TERRA) baik 
secara persial maupun secara simultan terhadap kepuasan masyarakat. Dengan demikian dapat ditemukan persamaan regresi dalam penelitian ini adalah sebagai berikut:

$\mathrm{Y}=\mathrm{a}+\mathrm{b} 1 \mathrm{X} 1+\mathrm{b} 2 \mathrm{X} 2+\mathrm{b3X3}+\mathrm{b4X4}+\mathrm{b5X5}$

$\mathrm{Y}=$ Kepuasan Nasabah

$\mathrm{X} 1=$ Tangible

$\mathrm{X} 2=$ Empathy

$\mathrm{X} 3=$ Reliability

$\mathrm{X} 4=$ Responsiveness

$\mathrm{X} 5=$ Assurance

4. Analisa korelasi

Analisa korelasi adalah satu teknik statistic yang digunakan untuk mengukur keeratan hubungan antara kedua variable (Widyono, 1999). Dalam penelitian ini, hubungan antara kedua variable kepuasan nasabah dan dimensi kualitas pelayanan (tangibles, empathy, reliability, responsiveness dan assurance $=$ TERRA) dianalisis dengan menggunakan korelasi bivariate (bivariate correlation) melalui person correlation. Rumus dari koefisien korelasi person ini adalah :

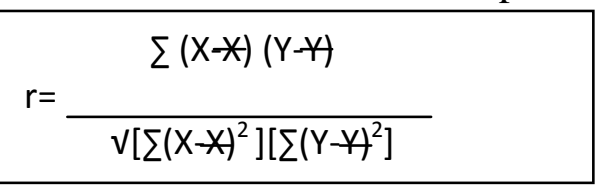

Dimana : $r=$ Koefesian Korelasi

$\mathrm{n}=$ Ukuran sampel

$\mathrm{x}=$ Nilai variable bebas

$\mathrm{y}=$ Nilai variable terikat

5. Analisa Koefisien determinasi

Koefisien determinasi adalah suatu alat ukur yang digunakan untuk mengetahui sejauh mana tingkat hubungan antar variable $\mathrm{X}$ dan $\mathrm{Y}$. koefisien ini dapat ditentukan berdasarkan hubungan antara dua macam variasi yaitu ;

1. Variasi Y terhadap garis regresi ( Y)

2. Variasi terhadap rata - ratanya $(\mathrm{Y})$

Ada 2 jenis hubungan antara variable $X$ dan $Y$

a. Hubungan ssempurna antara variable $X$ dan $Y$

b. Tidak ada hubungan antara variable $\mathrm{X}$ dan $\mathrm{Y}$

Rumus koefisien determinasi adalah;

$\mathrm{Kd}=\mathrm{r}^{2} \mathrm{X} 100 \%$

Dimana:

$\mathrm{Kd}=$ Koefisien determinasi

$\mathrm{r}^{2}=$ jumlah kuadrat regresi

6. Uji T

Ujii T pada dasarnya menunjukan seberapa jauh pengaruh variable bebas secara individual dalam menerangkan variasi variable terikat.

Formula Hipotesis:

Ho : bi $=0$, Artinya variable bebas bukan merupakan penjelas yang signifikan terhadap variable terikat.

Ha : bi \# 0 , Artinya variable bebas merupakan penjelas yang signifikan terhadap variable terikat.

Untuk menguji hipotesis tersebut digunakan statistic t yang dihitung dengan cara sebagai berikut:

$$
\mathrm{T}=\frac{\mathrm{b}}{\mathrm{Sb}}
$$


Dimana $\mathrm{b}$ adalah nilai parameter dan $\mathrm{Sb}$ adalah Standar error dari $\mathrm{b}$, standar eror dari masing - masing parameter hitung dari akar varians masing - masing.

Untuk megetahui kebenaran hipotesis digunakan criteria bila t hitung $>\mathrm{t}$ table maka Ho ditolak dan Ha diterima, artinya ada pengaruh antara variable bebas terhadap variable terikat dengan derajat keyakinan yang digunakan sebesar $a=1 \%, a=5 \%, a=10 \%$, begitu pula sebaliknya bila $\mathrm{t}$ terhitung $<\mathrm{t}$ table maka menerima Ho dan menolak Ha artinya tidak ada pengaruh antara variable bebas terhadap variable terikat.

7. Uji F

Uji F dilakukan untuk mengetahui pengaruh variable bebas secara besama- sama terhadap variable terikat. Rumusan hipotesis yang di uji:

Ho : $\mathrm{b} 1=\mathrm{b} 2=\mathrm{b} 3=\mathrm{b} 4=0$ berarti secara bersama - sama tidak ada pengaruh antara variable bebas terhadap variable terikat.

Untuk menguji kebenaran hipotesis altrnatif dilakukan Uji F dengan rumus sebagai berikut ( Gujarati, 1978):

F terhitung $=\frac{\mathrm{R}^{2} /(\mathrm{k}-1)}{(1-\mathrm{R} 2) /(\mathrm{N} / \mathrm{k})}$

Bila $\mathrm{F}$ dihitung $>\mathrm{F}$ table maka Ho ditolak dan Ha diterima artinya variable bebas secara bersama - sama merupakan penjelas yang signifikan terhadap variable terikat. Bila dihitung < F table maka Ho diterima Ha ditolak artinya semua variable bebas secara besama - sama bukan merupakan variable penjelas yang signifikan terhadap variable teikat.

\section{HASIL DAN PEMBAHASAN}

Deskripsi Variabel Penelitian

Dalam mendeskripsikan variabel penelitian, digunakan analisa statistik deskriptif untuk menjelaskan profil responden penelitian yang terdiri dari jenis kelamin, usia, pekerjaan dan tingkat pendidikan. Selanjutnya analisa deskriptif ini juga akan dipaparkan distribusi frekuensi jawaban responden terhadap masing - masing butir pertanyaan yang digunakan untuk mengungkap variabel penelitian yaitu tangibles, empathy, reliability, responsiveness, assurance dan kepuasan masyarakat.

Karakteristik Responden

\section{Tabel 2}

Distribusi Frekuensi Responden

Berdasarkan Jenis Kelamin

\begin{tabular}{|l|c|c|}
\hline & Frequency & Percent \\
\hline Pria & 47 & 47.0 \\
Wanita & 53 & 53.0 \\
Total & 100 & 100.0 \\
\hline
\end{tabular}

Sumber: Data di olah sendiri, 2013

Tabel 4 memperlihatkan distribusi frekuensi responden berdasarkan jenis kelamin. Berdasarkan tabel tersebut dapat diketahui bahwa mayoritas responden penelitian ini adalah mereka yang berjenis kelamin wanita yaitu sebanyak 53 orang atau sekitar $53 \%$. Sedangkan sisanya sebanyak 47 orang adalah mereka yang berjenis kelamin Pria atau sebanyak 47\%. Data responden berdasarkan usia dapat dilihat pada tabel 4.2 Berdasarkan tabel tersebut dapat dilihat bahwa mayoritas respo nden penelitian ini adalah berusia 31-50 tahun yaitu sebanyak 29 orang atau sekitar $29 \%$. 
Tabel 3

Distribusi Frekuensi Responden

Berdasarkan Usia

\begin{tabular}{|l|c|c|}
\hline & Frequency & Percent \\
\hline $17-22$ tahun & 23 & 23.0 \\
$23-30$ tahun & 25 & 25.0 \\
$31-50$ tahun & 29 & 29.0 \\
50 tahun ke atas & 23 & 23.0 \\
Total & 100 & 100.0 \\
\hline
\end{tabular}

Sumber: Data di olah, 2013

Kemudian diikuti oleh kelompok responden berusia antara 23 - 30 tahun yaitu sebanyak 25 orang atau sekitar $25 \%$. Sedangkan responden yang berusia 17-22 tahun dan diatas 50 tahun adalah masing - masing sebanyak 23 orang atau $23 \%$.

Pada tabel 4. berikut diperlihatkan data responden berdasarkan status responden:

\section{Tabel 4}

Distribusi Frekuensi Responden

Berdasarkan Status

\begin{tabular}{|l|c|c|}
\hline & Frequency & Percent \\
\hline Kawin & 57 & 57.0 \\
Tidak Kawin & 43 & 43.0 \\
Total & 100 & 100.0 \\
\hline
\end{tabular}

Sumber: Data di olah, 2013

Distribusi frekuensi responden berdasar-kan status dapat dilihat pada tabel Berdasarkan tabel tersebut dapat dilihat bahwa mayoritas responden penelitian ini adalah kawin yaitu sebanyak 57 orang atau sekitar 57\%. Kemudian tidak kawin sebanyak 43 orang atau sekitar $43 \%$.

Pada tabel 5 berikut diperlihatkan data responden berdasarkan pendidikan terakir

Responden

Tabel 5

Distribusi Frekuensi Responden Berdasarkan Pendidikan terakhir

\begin{tabular}{|l|c|c|}
\hline & Frequency & Percent \\
\hline SD & 1 & 1.0 \\
SLTP & 8 & 8.0 \\
SMA & 47 & 47.0 \\
D1-DIII & 17 & 17.0 \\
S1 & 21 & 21.0 \\
S2 & 6 & 6.0 \\
Total & 100 & 100.0 \\
\hline
\end{tabular}

Sumber: Data di olah, 2013

Profil responden penelitian berdasarkan latar belakang pendidikan ditunjukkan oleh tabel 5 Tabel tersebut memperlihatkan bahwa mayoritas responden penelitian ini adalah mereka yang memiliki latar belakang pendidikan SMA yaitu sebanyak 47 orang atau sekitar $47 \%$. Kemudian diikuti oleh mereka yang berpendidikan S1 sebanyak 21 orang (21\%), D1 - DIII 
sebanyak 17 orang (17\%), SLTP sebanyak 8 orang (8\%), Sarjana S2 sebanyak 6 orang $(6 \%)$, dan SD ada 1 orang.

\section{Tabel 6}

Distribusi Frekuensi Responden Berdasarkan Pekerjaan

\begin{tabular}{|l|c|c|}
\hline & Frequency & Percent \\
\hline PNS/TNI/POLRI & 13 & 13.0 \\
Pegawai swasta & 15 & 15.0 \\
Wiraswasta & 24 & 24.0 \\
Pelajar & 11 & 11.0 \\
Lainnya & 37 & 37.0 \\
Total & 100 & 100.0 \\
\hline
\end{tabular}

Sumber: Data diolahi, 2013

Tabel 6 menunjukkan bahwa mayoritas responden bekerja sebagai lainnya (ibu rumah tangga, Pedagang) yaitu sebanyak 37 orang atau sekitar 37\%. Selanjutnya diikuti oleh mereka yang memiliki pekerjaan sebagai Wiraswsata sebanyak 24 orang atau sekitar $24 \%$ selanjutnya responden yang bekerja sebagai Pegawai Swasta 15 orang atau sekitar 15\%. Kemudian PNS/Polri/TNI Mereka yang bekerja sebagai pelajar / mahasiswa sebanyak 13 orang (13\%). Dan pelajar ada sebanyak 11 orang atau $11 \%$.

\section{Uji Validitas}

Suatu skala pengukuran disebut valid bila ia melakukan apa yang seharusnya dilakukan dan mengukur apa yang seharusnya diukur (Kuncoro, 2003; Sekaran, 2003).

Untuk mengetahui apakah instrumen pertanyaan valid atau tidak valid, maka digunakan korelasi bivariat (bivariate correlation) yaitu mengkorelasikan masing - masing butir pertanyaan terhadap nilai total butir pertanyaan. Apabila sebuah pertanyaan berkorelasi signifikan dengan nilai total butir pertanyaan maka instrumen pertanyaan tersebut dinyatakan valid, dan sebaliknya (Ghozali, 2005). Tabel 4.6 - 4.11 memperlihatkan hasil analisa validitas butir pertanyaan yang mengukur masing - masing variabel penelitian yaitu variabel tangibles (X1), empathy (X2), reliability (X3), responsiveness (X4), assurance (X5) dan kepuasan Nasabah (Y).

\section{Validitas Butir Pertanyaan Variabel Tangibles}

Dalam penelitian ini, variabel tangibles (X1) diukur atau dioperasionalisasikan melalui empat butir pertanyaan. Berdasarkan hasil analisa validitas yang ringkas pada tabel 4.6 terlihat bahwa semua butir pertanyaan (4 pertanyaan) yang mengukur variabel tangibles dinyatakan valid. Hal ini dapat dibuktikan bahwa keempat butir pertanyaan tersebut berkorelasi signifikan terhadap nilai total tangibles pada tingkat 0,03 atau 3\% seperti yang diperlihatkan pada tabel berikut ini:

\section{Tabel 7}

Validitas Butir Pertanyaan Variabel Tangibles (X1)

\begin{tabular}{|c|c|c|}
\hline Pertanyaan & $\begin{array}{c}\text { Nilai Total } \\
\text { Tangibles }\end{array}$ & Keputusan \\
\hline$(\mathrm{X} 1.1)$ & 0.480 & Valid \\
\hline$(\mathrm{X} 1.2)$ & 0.686 & Valid \\
\hline$(\mathrm{X} 1.3)$ & 0.489 & Valid \\
\hline$(\mathrm{X} 1.4)$ & 0.562 & Valid \\
\hline
\end{tabular}

Sumber: Data di olah ,2013

Dari tabel 7 butir pertanyaan X1.1 dengan nilai 0,480 berarti valid begitu juga dengan X1.2 (0.686) X1.3 (0.489) dan X1.4 (0,562). butir pertanyaan di dapat valid semua. 


\section{Validitas Butir Pertanyaan Variabel Empathy}

Variabel empathy (X2) diukur atau dioperasionalisasikan melalui empat pertanyaan. Berikut ini diperlihatkan ringkasan hasil analisa validitas terhadap butir pertanyaan variabel empathy.

Berdasarkan hasil analisa validitas yang ringkas pada tabel 4.7 terlihat bahwa semua butir pertanyaan (4 pertanyaan) yang mengukur variabel empathy dinyatakan valid. Hal ini dapat dibuktikan bahwa ke empat butir pertanyaan tersebut berkorelasi signifikan terhadap nilai total pertanyaan empathy pada tingkat 0,03 atau 3\% seperti yang diperlihatkan pada tabel berikut ini.

Tabel 8

Validitas Butir Pertanyaan Variabel Empathy (X2)

\begin{tabular}{|c|c|c|}
\hline Pertanyaan & $\begin{array}{c}\text { Nilai Total } \\
\text { Empathy }\end{array}$ & Keputusan \\
\hline$(\mathrm{X} 2.1)$ & 0.471 & Valid \\
\hline$(\mathrm{X} 2.2)$ & 0.587 & Valid \\
\hline$(\mathrm{X} 2.3)$ & 0.552 & Valid \\
\hline$(\mathrm{X} 2.4)$ & 0.328 & Valid \\
\hline
\end{tabular}

Sumber: Data di olah, 2013

Dari tabel 8 butir pertanyaan X2.1 dengan nilai 0,471 berarti valid begitu juga dengan X2.2 (0.587) X2.3 (0.552) dan X2.4 (0,328). butir pertanyaan di dapat valid semua.

\section{Validitas Butir Pernyataan Variabel Reliability}

Variabel reliability (X3) diukur atau dioperasionalisasikan melalui empat butir pertanyaan.

Tabel 9

Validitas Butir Pertanyaan Variabel Reliability (X3)

\begin{tabular}{|c|c|c|}
\hline Pertanyaan & $\begin{array}{l}\text { Nilai Total } \\
\text { Reliability }\end{array}$ & Keputusan \\
\hline (X3.1) & 0.586 & Valid \\
\hline (X3.2) & 0.677 & Valid \\
\hline (X3.3) & 0.670 & Valid \\
\hline (X3.4) & 0.574 & Valid \\
\hline
\end{tabular}

Sumber: Data diolah, 2013

Tabel 98 memperlihatkan ringkasan hasil analisa validitas terhadap butir pertanyaan variabel reliability atau keandalan. Tabel tersebut memperlihatkan bahwa nilai korelasi masing - masing butir pertanyaan X3.1 dengan niali $(0,586)$ X3.2 dengan nilai $(0,677)$ X3.3 dengan nilai $(0,670)$ X3.4 dengan nilai $(0,574)$.

Berdasarkan hasil analisa validitas terhadap keempat butir pertanyaan yang digunakan untuk mengukur dimensi reliability yang diringkas dan disajikan pada tabel 9 dapat diinterpretasikan bahwa semua butir pertanyaan (4 pertanyaan) yang mengukur variabel reliability dinyatakan valid.

Hal ini dapat dibuktikan dimana keempat butir pertanyaan tersebut berkorelasi signifikan terhadap nilai total pertanyaan reliability pada 0,03 atau $3 \%$ seperi yang diperlihatkan pada tabel berikut ini:

\section{Validitas Butir Pertanyaan Variabel Responsiveness}

Variabel responsiveness (X4) diukur dengan menggunakan empat butir pertanyaan. Tabel 10 memperlihatkan ringkasan hasil analisa validitas terhadap butir pertanyaan variabel responsiveness atau daya tanggap. 
Tabel 10

Validitas Butir Pertanyaan Variabel Responsiveness (X4)

\begin{tabular}{|c|c|c|}
\hline Pertanyaan & Nilai Total Responsiveness & Keputusan \\
\hline (X5.1) & 0.662 & Valid \\
\hline (X5.2) & 0.667 & Valid \\
\hline (X5.3) & 0.524 & Valid \\
\hline (X5.4) & 0.546 & Valid \\
\hline
\end{tabular}

Sumber: Data diolah ,2013

Tabel 10 memperlihatkan nilai korelasi butir pertanyaan dengan nilai total responsiveness adalah X4.1 dengan nilai 0,573 X4.2 dengan nilai 0,593 X4.3 dengan nilai 0,513 dan X4.4 dengan nilai 0,185 .

Berdasarkan hasil analisa validitas terhadap keempat butir pertanyaan yang digunakan untuk mengukur dimensi responsiveness yang diringkas dan disajikan pada tabel 4.9 dapat diinterpretasikan bahwa tiga butir pertanyaan (3 pertanyaan) yang mengukur variabel resposiveness dinyatakan valid sedangkan X4.4 tidak valid. Hal ini dapat dibuktikan dimana ketiga pertanyaan tersebut berkorelasi signifikan terhadap nilai total pertanyaan responsiveness pada tingkat 0,03 atau $3 \%$ seperti yang diperlihatkan pada tabel 4.9 ini X4.4 di bawah tingkat 0.03 atau $3 \%$.

\section{Validitas Butir Pertanyaan Variabel Assurance}

Variabel assurance (X5) diukur atau dioperasionalisasikan melalui empat butir pertanyaan. Tabel 11 memperlihatkan ringkasan hasil analisa validitas terhadap butir pertanyaan variabel assurance atau keandalan. Tabel tersebut memperlihatkan nilai butir pertanyaan dengan nilai total assurance adalah X5.1 dengan nilai 0,662 X5.2 dengan nilai 0,667 X5.3 dengan nilai 0,524 dan X5.4 dengan nilai 0,546.

Berdasarkan hasil analisa validitas terhadap keempat butir pertanyaan yang digunakan untuk mengukur dimensi responsiveness yang diringkas dan disajikan pada tabel dapat diintreprestasikan bahwa semua butir pertanyaan (4 pertanyaan) yang mengukur variabel assurance dinyatakan valid. Hal ini dapat dibuktikan dimana keempat butir pertanyaan tersebut berkorelasi signifikan terhadap nilai total pertanyaan assurance pada tingkat 0,03 atau 3\% yang diperlihatkan pada tabel berikut.

Tabel 11

Validitas Butir Pertanyaan Variabel Assurance (X5)

\begin{tabular}{|c|c|c|}
\hline Pertanyaan & Nilai Total Responsiveness & Keputusan \\
\hline (X4.1) & 0.573 & Valid \\
\hline (X4.2) & 0.593 & Valid \\
\hline (X4.3) & 0.513 & Valid \\
\hline (X4.4) & 0.185 & Valid \\
\hline
\end{tabular}

Sumber: Data diolah, 2013

Variabel Kepuasan Nasabah

Kepuasan Nasabah (Y) diukur atau dioperasionalisasikan dengan menggunakan empat butir pertanyaan.

Tabel 12

Validitas Butir Pertanyaan Variabel Kepuasan (Y)

\begin{tabular}{|c|c|c|}
\hline Pertanyaan & Nilai Total Kepuasan Nasabah & Keputusan \\
\hline (Y.1) & 0.497 & Valid \\
\hline (Y.2) & 0.557 & Valid \\
\hline (Y.3) & 0.467 & Valid \\
\hline (Y.4) & 0.371 & Valid \\
\hline
\end{tabular}

Sumber: Data diolah, 2013 
Tabel 12 memperlihatkan ringkasan hasil analisa validitas terhadap butir pertanyaan variabel Kepuasan Nasabah. Tabel tersebut memperlihatkan nilai korelasi butir pertanyaan dengan nilai total kepuasan Nasabah adalah Y1 dengan nilai 0,497. Y2 dengan 0.557. Y3 dengan nilai 0,467 , dan Y4 dengan nilai 0,371.

Berdasarkan hasil analisa validitas terhadap keempat butir pertanyaan yang digunakan untuk mengukur variabel kepuasan nasabah yang diringkas dan disajikan pada tabel 12 dapat diintreprestasikan bahwa semua butir pertanyaan (4 pertanyaan) yang mengukur variabel kepuasan nasabah dinyatakan valid. Hal ini dapat dibuktikan dimana keempat butir pertanyaan tersebut berkorelasi signifikan terhadap nilai total pertanyaan kepuasan masyarakat pada tingkat 0,03 atau $3 \%$ yang diperlihatkan pada tabel berikut.

\section{Uji Reliabilitas}

Menurut Sekaran (2003:422) reliability is the consistency and stability of the measuring instrument. Secara umum, definisi tersebut dapat diartikan bahwa reliabilitas merupakan konsistensi dan stabilitas dari pengukuran instrumen. Dengan demikian, reliabilitas mencakup dua hal utama yaitu stabilitas ukuran dan konsistensi internal ukuran. Untuk mengetahui reliabilitas variabel tangibles, empathy, reliability, responsiveness, assurance dan kepuasan nasabah digunakan Cronbach's alpha minimal 0,60 (Sekaran, 2003). Tabel berikut ini memperlihatkan hasil analisis reliabilitas atas variabel penelitian.

\section{Analisa Korelasi}

Analisis korelasi merupakan suatu teknik statistik yang digunakan untuk mengukur keeratan hubungan antara dua variabel (Kuncoro, 2003). Dalam penelitian ini, hubungan antar variabel penelitian yaitu tangibles (X1), empathy (X2), responsiveness (X4), assurance (X5) dan kepuasan nasabah (Y) dianalisa secara melalui korelasi bivariat (bivariate correlation) dengan menggunakan Person's Correlation. Hasil analisa korelasi tersebut disajikan pada tabel sedangkan output lengkap SPSS dapat dilihat pada lampiran. Dengan kata lain, semua instrumen pertanyaan yang dipergunakan adalah stabil dan konsisten dalam mengukur masing-masing variabel (tangibles, empathy, reliability, responsiveness, assurance dan kepuasan masyarakat). Outpun lengkap SPSS dapat dilihat pada lampiran.

Tabel 13

Uji Reliablitas

\begin{tabular}{|l|c|c|l|}
\hline \multicolumn{1}{|c|}{ Variabel } & Jumlah Instrumen & Cronbach's Alpha & Keputusan \\
\hline Tangibles $(\mathrm{X} 1)$ & 4 & 0,753 & Andal \\
\hline Empathy $(\mathrm{X} 2)$ & 4 & 0,692 & Andal \\
\hline Reliability $(\mathrm{X} 3)$ & 4 & 0,809 & Andal \\
\hline Responsiveness $(\mathrm{X} 4)$ & 4 & 0,672 & Andal \\
\hline Assurance $(\mathrm{X} 5)$ & 4 & 0,789 & Andal \\
\hline Kepuasan Nasabah (Y) & 4 & 0,684 & Andal \\
\hline
\end{tabular}

Sumber: Data di olah sendiri, 2013

Tabel 13 menunjukkan bahwa nilai Cronbach's alpha untuk semua variabel penelitian adalah diatas 0,60 seperti nilai Cronbach alpha variabel tangibles $(0,753)$, empathy $(0,692)$, reliability $(0,809)$, responsiveness $(0,672)$, assurance $(0,789)$ dan kepuasan nasabah $(0,684)$. Dengan demikian dapat diartikan bahwa semua variabel dalam penelitian ini adalah reliabel atau andal (Sekaran, 2003). 
Tabel 14

Korelasi Antara Variabel Tangibles, Empathy, Reliability, Responsiveness, Assurance dan Kepuasan Nasabah.

\begin{tabular}{|l|c|l|l|l|l|l|}
\hline \multicolumn{1}{|c|}{ Variabel } & $\mathbf{Y}$ & \multicolumn{1}{c|}{$\mathbf{X 1}$} & \multicolumn{1}{c|}{$\mathbf{X 2}$} & \multicolumn{1}{c|}{$\mathbf{X 3}$} & \multicolumn{1}{c|}{ X4 } & \multicolumn{1}{c|}{ 55 } \\
\hline Kepuasan & 1 & - & - & - & - & - \\
\hline Tangibles & 0.694 & 1 & - & - & - & - \\
\hline Empathy & 0.668 & - & 1 & - & - & - \\
\hline Reliability & 0.694 & - & - & 1 & - & - \\
\hline Responsiveness & 0.710 & - & - & - & 1 & - \\
\hline Assurance & 0.654 & - & - & - & - & 1 \\
\hline
\end{tabular}

Sumber: Data di olah sendiri, 2013

Berdasarkan hasil analisa korelasi antar variabel penelitian yang disajikan pada tabel 14 diatas, dengan pedoman nilai koefesiennya, semakin mendekati 1 dan -1 maka hubungan kuat dan apabila mendekati 0 maka hubungan lemah. Pada tabel terlihat bahwa nilai tangibles 0,694 ini artinya hubungannya kuat terhadap kepuasan. Empathy dengan nilai 0,668 ini artinya hubungan kuat terhadap kepuasan karena nilai mendekati 1. Reliability dengan nilai 0,694 ini artinya hubungan kuat terhadap kepuasan nasabah. Responsiveness 0,710 artinya punya hubungan kuat terhadap kepuasan. Dan Assurance dengan nilai 0,654 ini artinya mempunyai hubungan kuat terhadap kepuasan nasabah.

Pada tabel berikut disajikan hasil uji determinasi:

Model Summary ${ }^{b}$

\begin{tabular}{|l|c|r|r|rr|}
\hline Model & R & R Square & Adjusted R Square & \multicolumn{2}{|c|}{ Std. Error of the Estimate } \\
\hline 1 & $.819^{\mathrm{a}}$ & .671 & .653 & & 1.345 \\
\hline
\end{tabular}

a. Predictors: (Constant), Assurance, Tangible, Responsiveness, Empathy, Reliability

b. Dependent Variable: Kepuasan

Sumber : Data di olah, 2013

Dari tabel diatas dapat dijelaskan angka $\mathrm{R}$ square adalah 0,671 ( adalah pengkuadratan dari koefisien korelasi atau 0,819 x 0,819). R square bisa disebut koefisien determinasi, yang dalam hal ini berarti $67,1 \%$ variabel yang dipilih pada variabel independen yaitu tangibles, empathy, reliability, responsiveness, dan assurance, dapat menerangkan variabel dependen yaitu kepuasan nasabah, sedangkan sisanya 32,9\% diterangkan oleh faktor lain yang tidak di bahas pada penelitian ini.

\section{Analisa Pengujian Hipotesis}

Untuk melihat pengaruh kualitas pelayanan terhadap kepuasan nasabah maka digunakan regresi berganda. 


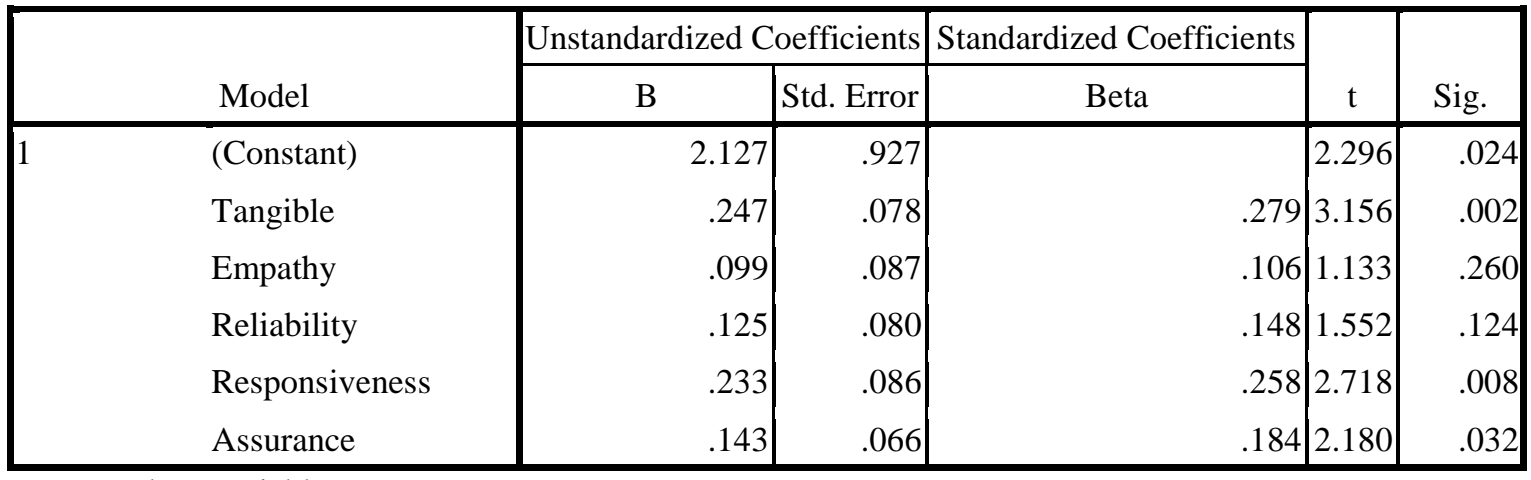

a. Dependent Variable: Kepuasan

Sumber : Data yang di olah, 2013

Berdasarkan hasil analisa regresi berganda yang disajikan pada tabel coefficients terlihat besarnya nilai konstanta (a) adalah 2,127. Sedangkan nilai koefisien regresi (beta) untuk variabel tangibles $(0,247)$, empathy $(0,099)$, reliability $(0,125)$, responsiveness $(0,233)$, dan assurance $(0,143)$. Dengan demikian, dapat dikemukakan persamaan regresi berganda adalah:

$Y=2,127+0,247 X_{1}+0,099 X_{2}+0,125 X_{3}+0,233 X_{4}+0,143 X_{5}$

Dimana:

Y =Kepuasan Nasabah

$\mathrm{a}=$ Konstanta

$\mathrm{X}_{1}=$ Tangibles

$\mathrm{X}_{2}=$ Empathy

$\mathrm{X}_{3}=$ Reliability

$\mathrm{X}_{4}=$ Responsiveness

$\mathrm{X}_{5}=$ Assurance

$\mathrm{e}=$ error term

Persamaan regresi berganda diatas secara statistik dapat diinterpretasikan sebagai berikut:

a) Apabila terjadi peningkatan variabel tangibles sebesar 1 satuan dengan asumsi variabel empathy, reliability, responsiveness, dan assurance tetap, maka akan mengakibatkan peningkatan kepuasan nasabah sebesar 0,247 satuan.

b) Apabila terjadi peningkatan variabel empathy sebesar 1 satuan dengan asumsi tangibles, reliability, responsiveness, dan assurance tetap, maka akan mengakibatkan peningkatan kepuasan nasabah sebesar 0,099 satuan.

c) Apabila terjadi peningkatan variabel reliability sebesar 1 satuan dengan asumsi variabel tangibles, empathy, responsiveness, dan assurance tetap, maka akan mengakibatkan peningkatan kepuasan nasabah sebesar 0,125 satuan.

d) Apabila terjadi peningkatan variabel responsiveness sebesar 1 satuan dengan asumsi variabel tangibles, empathy, reliability, dan assurance tetap, maka akan mengakibatkan peningkatan kepuasan nasabah sebesar 0,233 satuan.

e) Apabila terjadi peningkatan variabel assurance sebesar 1 satuan dengan asumsi tangibles, empathy, reliability, dan responsiveness tetap, maka akan mengakibatkan peningkatan kepuasan nasabah sebesar 0,143 satuan.

\section{Uji t (t-test)}

Untuk melakukan pengujian hipotesis secara parsial tentang pengaruh Kualitas Pelayanan terhadap kepuasan nasabah pada PT Bank Mega Syariah Padang, maka dapat dilihat dari ringkasan hasil analisa regresi yang disajikan pada tabel coefficients. tabel tersebut memperlihatkan bahwa nilai koefisien regresi (beta) untuk masing - masing variabel bebas adalah sebagai berikut: 
a) Nilai koefisien regresi (beta) variabel tangibles adalah 3,156 dengan tingkat signifikansi sebesar 0,002. Besarnya nilai signifikansi tersebut berada di bawah 0,05. dengan demikian, dapat disimpulkan bahwa variabel tangibles (X1) berpengaruh signifikan terhadap kepuasan nasabah dalam pemberian pelayanan pada Bank Syariah Mega Indonesia.

b) Nilai koefisien regresi (beta) variabel empathy adalah 1,133 dengan tingkat signifikansi sebesar 0,260. Besarnya nilai signifikansi tersebut berada di atas 0,05. Dengan demikian, dapat disimpulkan bahwa variabel empathy (X2) tidak berpengaruh signifikan terhadap kepuasan nasabah dalam dalam pemberian pelayanan pada PT Bank Mega Syariah Padang.

c) Nilai koefisien regresi (beta) variabel reliability adalah 1,552 dengan tingkat signifikansi sebesar 0,124. Besarnya nilai signifikan tersebut berada diatas 0,05. Dengan demikian, dapat disimpulkan bahwa variabel reliability (X3) tidak berpengaruh signifikan terhadap kepuasan nasabah dalam dalam pemberian pelayanan pada PT Bank Mega Syariah Padang.

d) Nilai koefisien regresi (beta) variabel responsiveness adalah 2,718 dengan tingkat signifikansi sebesar 0,008. Besarnya nilai signifikansi tersebut berada di bawah 0,05. Dengan demikian, dapat disimpulkan bahwa variabel responsiveness (X4) berpengaruh signifikan terhadap kepuasan nasabah dalam dalam pemberian pelayanan pada PT Bank Mega Syariah Padang.

e) Nilai koefisien regresi (beta) variabel assurance adalah 2,180 dengan tingkat signifikansi sebesar 0,032. Besarnya nilai signifikansi tersebut berada di bawah 0,05. Dengan demikian, dapat disimpulkan bahwa variabel assurance (X5) berpengaruh signifikan terhadap kepuasan nasabah dalam dalam pemberian pelayanan pada PT Bank Mega Syariah Padang.

Uji Simultan (Uji F) ANOVA $^{\mathrm{b}}$

\begin{tabular}{|ll|r|r|r|r|r|}
\hline Model & & Sum of Squares & df & Mean Square & F & Sig. \\
\hline 1 & Regression & 346.430 & 5 & 69.286 & 38.327 & $.000^{\text {a }}$ \\
& Residual & 169.930 & 94 & 1.808 & & \\
& Total & 516.360 & 99 & & & \\
\end{tabular}

a. Predictors: (Constant), Assurance, Tangible, Responsiveness, Empathy, Reliability

Sumber : Data di olah, 2013

Untuk melakukan pengujian hipotesis tentang pengaruh variabel tangibles, empathy, reliability, reponsiveness dan assurance serta simultan terhadap kepuasan nasabah pada PT Bank Mega Syariah Padang, maka dapat dilihat dari ringkasan hasil analisa regresi yang disajikan pada tabel anova. Tabel tersebut memperlihatkan bahwa nilai $\mathrm{F}$ (beta) adalah 38,327dengan tingkat signifikansi sebesar 0,000. Besarnya nilai signifikansi tersebut berada jauh di bawah 0,05. Dengan demikian, dapat disimpulkan bahwa dimensi tangibles, empathy, reliability, reponsiveness dan assurance secara simultan berpengaruh signifikan terhadap kepuasan nasabah dalam pemberian pelayanan pada PT Bank Mega Syariah Padang.

\section{Pembahasan}

Bagian ini berisikan pembahasan mengenai pengaruh masing - masing dimensi kualitas pelayanan (tangibles, empathy, reliability, reponsiveness dan assurance) baik secara parsial maupun simultan terhadap kepuasan nasabah dalam pemberian pelayanan pada nasabah PT Bank Mega Syariah Padang.

Sehubungan dengan hipotesis yang telah dikembangkan dimana dimensi kualitas pelayanan yaitu, tangibles, empathy, reliability, reponsiveness dan assurance baik secara 
parsial maupun secara simultan berpengaruh signifikan terhadap kepuasan nasabah dalam pemberian pelayanan pada nasabah PT Bank Mega Syariah Padang, hasil analisa statistik dengan menggunakan regresi berganda menunjukkan bahwa secara parsial dimensi tangibles, responsiveness, dan assurance, memiliki pengaruh signifikan terhadap kepuasan nasabah dalam pemberian pelayanan pada nasabah PT Bank Mega Syariah Padang. Selanjutnya, hasil analisa statistik dengan menggunakan regresi berganda menunjukkan bahwa secara parsial dimensi empathy dan reliability tidak memiliki pengaruh yang signifikan terhadap kepuasan nasabah dalam pemberian pelayanan pada nasabah PT Bank Mega Syariah Padang.

Secara simultan (Uji F), hasil analisa statistik dengan regresi berganda menunjukkan bahwa kelima dimensi kualitas pelayanan (tangibles, empathy, reliability, reponsiveness dan assurance) berpengaruh signifikan terhadap kepuasan nasabah dalam pemberian pelayanan pada nasabah PT Bank Mega Syariah Padang. Hal ini dapat dibuktikan dengan nilai uji-F sebesar 38,327 dengan tingkat signifikansi 0,000 atau jauh dibawah 0,05. dengan demikian hasil penelitian ini memberikan indikasi bahwa kelima dimensi kualitas pelayanan tersebut secara bersama - sama berpengaruh signifikan terhadap kepuasan nasabah dalam pemberian pelayanan pada nasabah PT Bank Mega Syariah Padang.

\section{SIMPULAN DAN IMPLIKASI PENELITIAN}

Berdasarkan hasil analisa dan pembahasan, maka dapat disimpulkan sebagai berikut:

1. Besarnya pengaruh kualitas pelayanan (tangibles, empathy, reliability, responsiveness, dan assurance) terhadap kepuasan nasabah pada PT Bank Mega Syariah Padang adalah $67,1 \%$ karena nilai koefesien determinasi $\left(\mathrm{R}^{2}\right) 0,671$ berarti $67,1 \%$ kepuasan nasabah di pengaruhi oleh variabel independent (tangibles, empathy, reliability, responsiveness, dan assurance) dan sisanya 32,9\% di pengaruhi oleh faktor lain.

2. Hasil analisa statistik dengan menggunakan regresi berganda menunjukkan bahwa secara parsial (Uji $\mathrm{T}$ ) dimensi kualitas pelayanan tangibles, responsiveness, dan assurance, berpengaruh signifikan terhadap kepuasan nasabah dalam pemberian pelayanan pada PT Bank Mega Syariah Padang, dengan variabel empathy, tidak memilki pengaruh signifikan terhadap kepuasan nasabah dalam pemberian pelayanan pada PT Bank Mega Syariah Padang.

\section{DAFTAR PUSTAKA}

Aziz, N. (2019). Pengaruh Kualitas Layanan Terhadap Kepuasan Nasabah SMS Banking Pada Bank Nagari Cabang Pembantu RSUP DR M Djamil Padang. https://doi.org/10.17605/OSF.IO/S3JVG

Aziz, N. (2019). Pengaruh Biaya, Angsuran Dan Kualitas Pelayanan Terhadap Kepuasan Nasabah Pembiayaan Bmt At-Taqwa Muhammadiyah Cabang Siteba Padang. https://doi.org/10.17605/OSF.IO/YVJAS

Fernandes, Y. D., \& Marlius, D. (2018). Peranan Customer Service Dalam Meningkatkan Pelayanan Kepada Nasabah Pada PT. Bank Pembangunan Daerah Sumatera Barat Cabang Utama Padang. https://doi.org/10.31227/osf.io/wrh3p

Kotler, Philip \& Amstrong, Gary, (2007). Dasar-dasar Pemasaran Jilid 1, Alih Bahasa Alexander ASindoro, Jakarta. PT. Macan Jaya Cemerlang 
Kotler, Philip \& Keller, Kevin Lane (2007), Manajemen Pemasaran, Edisi 12, Jakarta. PT. Macan Jaya Cemerlang

Kuncoro M (2003) Metode Riset Untuk Bisnis Dan Ekonomi, Bagian Meneliti Dan Menulis Skripsi, Erlangga, Jakarta

Marlius, D. (2018). Pengaruh Dimensi Kualitas Pelayanan Website Akademik Terhadap Kepuasan Mahasiswa Pada STIE "KBP”. Jurnal Ipteks Terapan. Volume 12. No. 2. Hal. 116-128. http://doi.org/10.22216/jit.2018.v12i2.633

Marlius, D. (2018). Loyalitas Nasabah Bank Nagari Syariah Cabang Bukittinggi Dilihat Dari Kualitas Pelayanan. Jurnal Pundi. Volume 1. No. 3. Hal.12-22. https://doi.org/10.31575/jp.v1i3.60

Mayliza, R. (2019). Analisis Customer Satisfaction Dan Behavioral Intention Dilihat Dari Service Quality, Food Quality Dan Price/Value Di Restoran Mc Donald's Depok. https://doi.org/10.31219/osf.io/e2jrt

Mayliza, R. (2019). Pengaruh Citra Perusahaan (Corporate Image) Dan Penanganan Keluhan (Complaint Handling) Terhadap Loyalitas Pelanggan (Loyality) Natasha Skin Care Di Kota Padang. https://doi.org/10.17605/OSF.IO/DF9XJ

Mirawati \& Fernos, J. (2019). Peranan Customer Service Dalam Meningkatkan Pelayanan Terhadap Nasabah Pada Bank Nagari Cabang Siteba Padang. https://doi.org/10.31227/osf.io/cq458

Mulyadi, H., \& Susanti, F. (2018). Pengaruh Penerapan Strategi Customer Relationship Marketing Terhadap Kepuasan Nasabah Pada PT. Pro Car International Finance Cabang Padang. https://doi.org/10.31227/osf.io/bhq8d

Putra, Y. E., \& Aziz, N. (2019). Pengaruh Kualitas Pelayanan Dan Kepuasan Pelanggan Terhadap Loyalitas Nasabah PT. Bank Rakyat Indonesia Cabang Padang. https://doi.org/10.31219/osf.io/hcsw2

Safitri, R. N., \& Marlius, D. (2017). Penerapan E-Banking Dalam Meningkatkan Jasa Dan Layanan Perbankan Di PT. Bank Rakyat Indonesia Cabang Padang. https://doi.org/10.31227/osf.io/gkv8t

Staton, W (2008) Pengertian Pemasaran www.google.com di akses tanggal 21 September 2013

Sekaran, U (2003) Research Methods For Business: Askill Buliding Aproach. Fourth Edition. Jhon Wiley \& Son.

Sugiyono. (2002) Metode Penelitian Administrasi. Alfabetha, Bandung

Tiza, M. F., \& Susanti, F. (2019). Pengaruh Kualitas Pelayanan Terhadap Kepuasan Pelanggan, Studi kasus pada perusahaan JNE Cabang Padang. https://doi.org/10.31227/osf.io/hx87m 
Tjiptono, (2000) Manajemen Pemasar an Jasa, Teori dan Praktik, Salemba Empat, Jakarta

Tjiptono. Fandy. (2004) Manajemen Jasa.

Ulfa, M., \& Mayliza, R. (2019). Pengaruh Kualitas Pelayanan Dan Kepuasan Pelanggan Terhadap Loyalitas Pelanggan PDAM Kota Padang. https://doi.org/10.31219/osf.io/spmgv 